\title{
Stereotactic Hypofractionated Irradiation for Metastatic, Inoperable, and Recurrent Malignancies: A Modern Necessity, rather than a Luxury
}

\author{
Sridhar P. Susheela, Swaroop Revannasiddaiah, and Ajaikumar Basavalingaiah \\ Department of RT, HealthCare Global, Bangalore Institute of Oncology, Bengaluru, Karnataka 560027, India \\ Correspondence should be addressed to Swaroop Revannasiddaiah; swarooptheone@gmail.com
}

Received 28 September 2014; Revised 6 December 2014; Accepted 9 December 2014; Published 28 December 2014

Academic Editor: Oliver Micke

Copyright (C) 2014 Sridhar P. Susheela et al. This is an open access article distributed under the Creative Commons Attribution License, which permits unrestricted use, distribution, and reproduction in any medium, provided the original work is properly cited.

\begin{abstract}
Stereotactic-irradiation combines highly conformal delivery of radiation to selected volumes at large doses per fraction, with the treatment completed typically within one to five fractions. The radiobiological equivalence of doses delivered by stereotacticirradiation (often beyond 80-100 Gy) is much higher in comparison to the doses achievable by conventional fractionation. At the high fraction sizes used in stereotactic-irradiation, evidence suggests the role of various radiobiological mechanisms of actions, which are not traditionally relatable with conventional radiotherapy. In spite of the accumulating evidence in favour of the efficacy of stereotactic irradiation in terms of improving local control and at times attaining increments in survival, the clinical adoption of the technique remains dismal. This review provides a brief description of the available evidence describing the benefits of stereotacticirradiation for the management of patients with oligometastases, unresectable malignancies and for disease recurrence after prior radiotherapy. Given the growing body of evidence illustrating the efficacy of stereotactic irradiation among patients with conditions which were previously often regarded as untreatable, it is likely that the widespread adoption of stereotactic irradiation may achieve cure in a few patients, while in the remainder providing prospects of long term local control. This could be a step in the direction of converting incurable malignancies into chronic controllable diseases.
\end{abstract}

\section{Introduction}

In the history of humanity's war against disease, there have been many instances wherein otherwise fatal diseases have been tactfully converted into chronic controllable conditions. As examples, while diabetes and hypertension remain largely incurable to this date, modern medicine has allowed countless persons with these diseases to lead nearly normal lives.

The field of oncology has seen its own share of successes; many situations which were uniformly fatal in the past, are now regarded as "treatable," even if not always "curable." An excellent example would be the case of metastatic receptor-positive breast cancer, where patients with multiple metastases are expected to survive for long periods with the optimized use of targeted therapy, hormone therapy, and focal irradiation.
The recent emergence of various technological innovations with regard to image guidance and precision radiotherapy has allowed the routine use of hypofractionated stereotactic radiotherapy in extracranial sites. This technique of "stereotactic body radiotherapy" (SBRT), also referred to by other acronyms, SABR (stereotactic ablative RT) and ESRT (extracranial stereotactic RT), happens to utilize high doses of radiation delivered in a single or a limited number of fractions (typically less than five) with very high conformality to the target area. Such an approach is bestowed with a very high therapeutic ratio, given that the biological effectiveness of doses deposited on the target tissue is very high (often beyond 100 Gray), while the doses to normal tissues are restricted to a minimum [1-3].

Despite the growing evidence in the favour of SABR for various indications, it remains clinically underutilized 
largely due to a lack of awareness of the potential that this new and emerging treatment modality holds. This review highlights the capabilities of SABR in treating conditions which could otherwise be undertreated or, even worse, be met with neglect.

\section{The Meaning of Stereotactic Ablative Radiotherapy (SABR)}

The use of fractionated radiotherapy (RT) utilizing doses in the order of 2 Gray (Gy) per fraction (conventional fractionation) has dominated the field of external beam RT for nearly a century. It must be remembered that conventional fractionation was evolved out of radiobiological concepts in an era where the X-ray energies were limited mostly to the kilovoltage range (having a poor penetrating power). In the absence of technology to focus the radiation upon the target volume with precision, the focus was mainly upon the enhancement of therapeutic ratio, which meant to optimize the effect upon the target, while limiting toxic effects upon normal tissues to a minimum [4-7].

In the recent decades, technological breakthroughs such as improvements in sectional imaging, intensity-modulation for conformal RT, and linear accelerators with the ability to perform high-precision RT have allowed the oncologist to experiment with hypofractionation, using higher-doses per fraction, typically completing treatment in a shorter period of time. The feasibility of extrapolation of the principles of stereotactic intracranial radiosurgery (which has been in utility for decades) onto extracranial sites had been demonstrated decades ago with conventional linear accelerators. This has been often referred to by various synonyms, such as "stereotactic body radiotherapy (SBRT)," extracranial stereotactic radiotherapy (ESRT), and sterotactic ablative radiosurgery (SABR). Of all the currently used nomenclatures, the term "SABR" (stereotactic ablative radiosurgery) hints at the technique's peculiar radiobiological ablative action [8-11].

SABR typically is delivered in a maximum of five fractions, with dose per fraction ranging from $5 \mathrm{~Gy}$ to $30 \mathrm{~Gy}$, depending upon the size and relative location of the target in relation to nearby critical structures. Additionally, the recent availability of image-guidance has conferred a reasonable degree of safety and reliability in the delivery of frameless SABR.

Experiments have demonstrated radiobiological differences between conventionally fractionated RT and SABR. While the radiobiological basis of conventionally fractionated $\mathrm{RT}$ is often discussed in terms of the $4 R$ s of radiobiology (reoxygenation of tumour cells, repopulation of normal tissues, reassortment of tumour cells into more sensitive phases of the cell cycle, and repair of sublethal damage), the use of hypofractionation in SABR has different radiobiological basis, which may include the ceramide pathway, the induction of antitumor immunity, and damage to the membranes, organelles, and vascular endothelium [12-21].
Potential mechanisms of the ablative effect of SABR [13-21] are
higher biologically effective dose,
modulation of the immunological response to the tumour,
vascular and endothelial damage,
cell and organelle membrane damage,
ceramide pathway activation,
eradication of dormant tumour stem cells.

The next sections in this review describe the potential benefits associated with the adoption of SABR in clinical conditions otherwise known to have dismal outcomes in terms of both local control and survival.

2.1. The Potential in Oligometasatic Disease. Recently, there has been a general acceptance in the subcategorization of metastatic disease into the categories of "oligometastases" and "multiple/disseminated metastases." The term "oligo"metastasis is applied for the condition having a presence of $\leq 5$ metastases all within $\leq 3$ sites. Given their limited volume, these are often considered "treatable" by the use of focal therapies such as surgery, radiofrequency ablation (RFA), and focussed RT $[22,23]$.

Surgical resection in general is invasive and may inflict morbidities and impact quality of life (QOL) adversely. Radiofrequency ablation (RFA) is less invasive in comparison to surgery but has its own set of limitations, most importantly in its inability to reach sites which are deep or closely related to critical structures. Further, the effectiveness of RFA can be diminished because of the heat-sink phenomenon which occurs due to the presence of blood vessels in the near proximity of the target tissue. The flowing blood within the vessels acts as a heat sink by carrying heat away from the site $[24,25]$. The use of SABR for oligometastases promises to offer more durable local control and at times long term survival in comparison to conventional RT. This section describes the recent literature regarding the use of SABR for oligometastases involving the spinal column, brain, liver, lungs, adrenals, and lymph nodes.

The use of SABR for spinal (vertebral) metastases confers not just the ability to spare the spinal cord but also allows the delivery of higher doses which result in better duration of local control in comparison to conventional RT in naive patients as well as among patients treated earlier with irradiation. The use of conventional RT for spinal metastases often achieves early palliation. However, it has been shown that most lesions treated with conventional RT progress at a median time of 3-6 months [26]. The use of SABR provides more prolonged local control in comparison to conventional RT. Yamada et al. have shown in a study involving 103 patients that the use of single fraction SABR (with doses of 18-24 Gy) provided a $90 \%$ local control rate, and a median time to local failure of 9 months. It was further noted that the dose of radiation delivered was a determinant of local response, while histology was not a determinant of local response [27]. Chang et al. in their study of 74 patients observed a 1-year 
TABLE 1: Recent literature regarding the use of SABR for spinal metastases.

\begin{tabular}{|c|c|c|}
\hline Study & Remarks & Conclusions \\
\hline Amdur et al. [30] & $\begin{array}{l}\text { Prospective phase-II trial }(n=21) .15 \text { Gy } \\
\text { single fraction SABR. }\end{array}$ & $\begin{array}{l}43 \% \text { pain relief rate, } 95 \% \text { LC rate. Most patients died of } \\
\text { systemic disease progression. }\end{array}$ \\
\hline Chang et al. [28] & Phase I/II design $(n=63)$. & $\begin{array}{l}\text { 1-year progression free incidence of } 84 \% \text {. Pattern of } \\
\text { failure analysis revealed two-mechanisms-one of } \\
\text { recurrence in bone adjacent to previously treated site } \\
\text { and the other of recurrence in epidural space adjacent } \\
\text { to the spinal cord. }\end{array}$ \\
\hline Yamada et al. [27] & $\begin{array}{l}\text { Single fraction SABR with doses of } \\
18-24 \text { Gy }(n=93) \text {. }\end{array}$ & $\begin{array}{l}90 \% \text { LC at median follow-up of } 15 \text { months. In all cases } \\
\text { death was due to systemic disease progression and } \\
\text { never due to local failure. }\end{array}$ \\
\hline Ryu et al. [31] & $\begin{array}{l}\text { Assessed ability of SABR to provide } \\
\text { durable pain relief }(n=49) \text {. }\end{array}$ & $\begin{array}{l}\text { Overall pain control rate of } 84 \% \text { at } 1 \text { year. Median } \\
\text { duration of pain relief was } 13.3 \text { months. }\end{array}$ \\
\hline RTOG 0631 [32] & $\begin{array}{l}\text { Study design included phase- } 2 \text { and } \\
\text { phase- } 3 \text { components. }\end{array}$ & $\begin{array}{l}\text { Phase } 2 \text { component demonstrated feasibility and safety } \\
\text { of SABR in large multi-institutional trial. Phase- } 3 \\
\text { component intends to assess pain relief and quality of } \\
\text { life. }\end{array}$ \\
\hline Gerszten et al. [33] & $\begin{array}{l}\text { Large prospective trial }(n=500) .69 \% \\
\text { patients had prior RT. Mean SABR dose } \\
\text { of } 20 \mathrm{~Gy} .\end{array}$ & $\begin{array}{l}\text { Long term pain control in } 86 \% \text {. } \\
\text { Noticeable neurological improvement in } 85 \% \text {. }\end{array}$ \\
\hline Milker-Zabel et al. [34] & $\begin{array}{l}\text { Retrospective analysis of SABR (median } \\
\text { dose of } 39.6 \text { Gy) used in } 18 \text { patients with } \\
\text { prior history of conventional RT. }\end{array}$ & $\begin{array}{l}\text { SABR safe for reirradiation. Improves symptom control } \\
\text { in comparison to supportive care. }\end{array}$ \\
\hline Moulding et al. [35] & $\begin{array}{l}\text { Used SABR adjuvantly after } \\
\text { decompressive surgery in } 20 \text { patients. }\end{array}$ & $\begin{array}{l}\text { Only } 5 \% \text { local failure at } 1 \text { year. No wound related } \\
\text { complications. }\end{array}$ \\
\hline Sohn and Chung [36] & $\begin{array}{l}\text { Critical review of } 31 \text { studies using SABR } \\
\text { for spinal metastases. }\end{array}$ & $\begin{array}{l}1 \text { year LC rates consistently above } 90 \% \text {. } \\
\text { Additional benefits include the feasibility of use in } \\
\text { previously irradiated patients, excellent spinal cord } \\
\text { sparing and can also be used after decompressive } \\
\text { surgery. }\end{array}$ \\
\hline
\end{tabular}

SABR: stereotactic ablative body radiotherapy; LC: local control.

progression free survival at $84 \%$ and observed no incidence of severe toxicity [28]. Gill et al. observed 1-year and 2-year local control to be $80 \%$ and $73 \%$, respectively [29]. Amdur et al. observed a $95 \%$ local control rate, with most patients succumbing to progressive disease elsewhere [30]. Ryu et al. noted an overall pain control rate of $84 \%$ at 1 year [31]. The RTOG 0631 aims to establish the feasibility of image guided SABR. The study holds a phase- $2 / 3$ design, and the results of the phase- 2 component have been published and they establish the feasibility and safety of image-guided SABR for patients with 1-3 vertebral metastases. The results of the phase- 3 component of the study are yet to be published and aim to assess the effectiveness of SABR on pain relief and quality of life in comparison with conventional RT [32]. An outline of the recent evidences for the use of SABR in spinal metastases is provided in Table 1 [30-36].

The use of stereotactic radiosurgery (SRS) and fractionated stereotactic radiotherapy (FSRT) for intracranial oligometastases has a long history of success in selected patient populations. Linskey et al. performed a systematic review of studies evaluating the benefit from adding an SRS boost after whole brain RT (WBRT) for brain metastases [37]. Level-I evidence was obtained, which proved that, among patients with a solitary brain metastases with a good performance status (KPS $\geq 70$ ), the use of SRS after WBRT improved long-term survival in comparison to WBRT alone. There was better local control and improved functional status noted among patients with one to four metastases. Patil et al. presented the results of a Cochrane Database Systematic review analysing 358 patients which indicated significant improvements in functional status with the integration of SRS/SRT to WBRT. Additionally, significant overall survival benefits were observed among the subgroup of patients with single-metastases and belonging to the RTOG RPA-1 category [38]. An outline of the trials and meta-analysis conducted regarding the use of SRS/SRT for brain oligometastases is provided in Table 2 [37-43].

The treatment of hepatic oligometastases can often involve a curative approach utilizing surgical resection as a corner-stone $[44,45]$. For patients who are inoperable, second-line options include the use of RFA, percutaneous acetic acid injection, percutaneous ethanol injection, LASER therapy, chemoembolization, and Yttrium-90 microspheres [46-49]. However, of late, SABR has been utilized in hepatic metastases and primaries with considerable success in terms of local control, consistently being above $70 \%$ at 1 year. Rusthoven et al. reported 100\% two-year local control rates among patients with maximum lesion diameter $<3 \mathrm{~cm}$ [50]. 
TABLE 2: Evidence for the integrating stereotactic irradiation with whole-brain RT for brain oligometastases.

\begin{tabular}{|c|c|c|}
\hline Study & Remarks & Conclusions \\
\hline RTOG 9508 [39] & $\begin{array}{l}333 \text { patients with } 1-3 \text { randomized to } \\
\text { WBRT with or without SRS boost. }\end{array}$ & $\begin{array}{l}\text { Reported improved functional ability in all patients. } \\
\text { Survival benefit with SRS boost was limited to patients } \\
\text { with single brain metastases. Survival advantage for } \\
\text { patients with high graded prognostic assessment scores } \\
(3.5-4) \text { irrespective of } 1,2 \text {, or } 3 \text { brain metastases. }\end{array}$ \\
\hline Aoyama et al. [40] & $\begin{array}{l}\text { Randomized trial comparing SRS alone } \\
\text { or SRS with WBRT in } 132 \text { patients with } \\
1-4 \text { brain metastases. }\end{array}$ & $\begin{array}{l}\text { Treatment with SRS alone (without WBRT) would lead } \\
\text { to higher risk of intracranial relapse. }\end{array}$ \\
\hline Kocher et al. [41] & $\begin{array}{l}199 \text { patients with } 1-3 \text { brain metastases } \\
\text { treated with SRS randomized to } \\
\text { observation versus WBRT. }\end{array}$ & WBRT after SRS reduces risk of intracranial relapse. \\
\hline Yamamoto et al. [42] & $\begin{array}{l}\text { Large study }(n=1194) \text { to assess if SRS } \\
\text { alone without WBRT as initial treatment } \\
\text { provides similar survival for patients with } \\
5-10 \text { brain metastases compared to } \\
\text { patients with } 2-4 \text { brain metastases. }\end{array}$ & $\begin{array}{l}\text { SRS alone without WBRT provides noninferior } \\
\text { responses in patients with } 5-10 \text { brain metastases in } \\
\text { comparison to patients with } 2-4 \text { brain metastases. }\end{array}$ \\
\hline Chang et al. [43] & $\begin{array}{l}58 \text { patients with } 1-3 \text { brain metastases. To } \\
\text { assess cognitive effects of SRS versus SRS } \\
\text { plus WBRT. }\end{array}$ & $\begin{array}{l}\text { Patients treated with SRS plus WBRT had greater risk of } \\
\text { significant decline in learning and memory functions } \\
\text { compared to patients who were treated with SRS alone. }\end{array}$ \\
\hline Linskey et al. [37] & $\begin{array}{l}\text { Systematic review of trials using SRS with } \\
\text { WBRT for newly diagnosed brain } \\
\text { metastases. }\end{array}$ & $\begin{array}{l}\text { Derived Level } 1 \text { recommendation that single dose SRS } \\
\text { along with WBRT leads to significantly longer survival } \\
\text { compared to WBRT alone among patients with good } \\
\text { performance status (KPS }>70 \text { ) with single metastasis. } \\
\text { Also, SRS with WBRT is better than WBRT alone in } \\
\text { terms of local control and maintenance of functional } \\
\text { status among patients with } 1-4 \text { metastases. }\end{array}$ \\
\hline Patil et al. [38] & $\begin{array}{l}\text { Cochrane Database Systematic Review } \\
\text { evaluating the use of WBRT alone versus } \\
\text { WBRT with SRS in } 358 \text { patients from two } \\
\text { trials. }\end{array}$ & $\begin{array}{l}\text { SRT after WBRT reduces local failure (HR } 0.27,95 \% \text { CI } \\
0.14-0.52) \text { and provides a statistically significant } \\
(P=0.03) \text { benefit in improved performance status } \\
\text { ( } 43 \% \text { versus } 28 \% \text { SRS with WBRT versus WBRT alone). } \\
\text { Subgroup analysis showed significant overall survival } \\
\text { benefits among RPA-1 patients with single metastasis. }\end{array}$ \\
\hline
\end{tabular}

SRS: stereotactic radiosurgery; WBRT: whole-brain radiotherapy; RPA: recursive partitioning analysis; HR: hazard ratio; KPS: Karnofsky Performance Status.

Lanciano et al. observed a dose-dependent increase in local control, with two-year local control rates being $75 \%$ and $38 \%$ for patients treated with a biologically equivalent dose (BED) of $>100 \mathrm{~Gy}_{10}$ and $<100 \mathrm{~Gy}_{10}$, respectively [51]. In 27 patients of unresectable liver metastases, Ambrosino et al. utilized image guided SABR and observed a 74.1\% rate of local control and $25.9 \%$ patients had complete response. They noted a $33 \%$ incidence of mild to moderate hepatic toxicity [52]. Lee et al. in their phase-I trial involving 68 patients noted that despite delivering a dose which was assumed to hold a $20 \%$ risk of radiation induced liver disease, there was no incidence of grades 3-5 liver toxicity. In addition to the low toxicity, they observed a 1-year local control rate of $71 \%$ and a median survival of 17.6 months [53-55] (Table 3).

The use of SABR for oligometastases in the lungs has been one of the early applications for SABR. Very high 1-year local control rates have been reported with minimal risk of major toxicities. Okunieff et al. utilized SABR (ten fractions of $5 \mathrm{~Gy}$ each) to both oligo-and multiple metastases. With a very low risk of toxicity ( $2 \%$ risk of grade- 3 toxicity), there was a very significant local control rate (94\%) and an improved median survival in comparison to contemporary standards of care
[56]. Rusthoven et al. used high dose SABR (three fractions of $20 \mathrm{~Gy}$ each) for patients with oligometastases to the lung and reported local control rates of $100 \%$ and $96 \%$ at 1 and 2 years, respectively [57]. Norihisa et al. in their retrospective study of 34 patients with oligometastatic lung disease treated with SABR noted a 2-year overall survival of $84.3 \%$ and local control rate of $90 \%$. They utilized 12 Gy fractions of SABR to a total dose of $48 \mathrm{~Gy}$ in 18 patients and $60 \mathrm{~Gy}$ in 16 patients. It was notable that no patient who received $60 \mathrm{~Gy}$ had local progression [58]. The recent evidence for the use of SABR in pulmonary oligometastases is outlined in Table 4 [56-60].

It is not uncommon in clinical practise to encounter patients of various malignancies to relapse in isolated lymph nodes after prior treatment with various modalities. The use of SABR for isolated oligometastases in lymph nodes is a very attractive option, especially when surgery is not feasible. It must be mentioned here that there is no consensus upon the ideal dose and fractionation of SABR for lymph nodal oligometastases, but the same must be based upon factors such as the site of the target, size of the target, and the proximity to critical structures. Even though very little published literature exists on the use of SABR for lymph 
TABLE 3: Evidence for the use of SABR in treating hepatic metastases.

\begin{tabular}{lll}
\hline Study & Remarks & Conclusions \\
\hline Rusthoven et al. [50] & $\begin{array}{l}\text { SABR (upto 20 Gy } \times 3 \mathrm{Fc} \text { ) in patients with 1-3 } \\
\text { hepatic metastases (none }>6 \mathrm{~cm} \text { ). }\end{array}$ & $\begin{array}{l}\text { Median survival 20.5 months; 100\% 2-year local control } \\
\text { rates if maximum diameter }<3 \mathrm{~cm} .\end{array}$ \\
\hline Katz et al. [54] & $\begin{array}{l}\text { Retrospective analysis of 69 patients with 174 } \\
\text { hepatic metastases treated with SABR (dose range } \\
30-55 \mathrm{~Gy}) .\end{array}$ & No grade-3 toxicity. 76\% LC at 10 months. \\
\hline & $\begin{array}{l}\text { Use of SABR (various doses) for 20 patients of } \\
\text { hepatic metastases from colorectal malignancies } \\
\text { who were not candidates for resection or radio } \\
\text { van der Pool et al. [55] }\end{array}$ & $\begin{array}{l}\text { SABR is a viable option for colorectal liver metastases } \\
\text { who are not candidates for resection or RFA. 2-year LC } \\
\text { and OS at 74\% and 83\%, respectively. Observed rate of } \\
\text { grade-3 toxicity at 10\%. }\end{array}$ \\
\hline Lanciano et al. [51] & $\begin{array}{l}\text { Use of SABR for patients with heavily pretreated } \\
\text { liver tumours and metastases. }\end{array}$ & $\begin{array}{l}\text { Dose-dependent increase in local control, with 2-year } \\
\text { LC being 75\% versus 38\% for BED of }>100 \text { Gy 10 versus } \\
<100 \text { Gy 10 (P }=0.04) .\end{array}$ \\
\hline Ambrosino et al. [52] & $\begin{array}{l}\text { Image guided SABR in 17 patients of unresectable } \\
\text { liver metastases. }\end{array}$ & $\begin{array}{l}\text { 74.1\% patients had inhibition of growth or size } \\
\text { reduction. 25.9\% patients had complete response. Mild } \\
\text { to moderate hepatic dysfunction in 33\% patients. }\end{array}$ \\
\hline Lee et al. [53] & $\begin{array}{l}\text { Phase-I trial }(n=68) \text { of SABR in hepatic } \\
\text { metastases. }\end{array}$ & $\begin{array}{l}\text { Even at a dose of assuming 20\% risk of radiation } \\
\text { induced liver disease, there was no incidence of grade } \\
\text { 3-5 liver toxicity. 1-year local control rate of 71\%. }\end{array}$ \\
\hline
\end{tabular}

LC: local control; BED: biologically equivalent dose; RFA: radiofrequency ablation; OS: overall survival; Fc: fraction.

TABLE 4: Evidence for the use of SABR in treating lung oligometastases.

\begin{tabular}{|c|c|c|}
\hline Study & Remarks & Conclusions \\
\hline Okunieff et al. [56] & $\begin{array}{l}\text { Used SABR }(5 \mathrm{~Gy} \times 10 \mathrm{Fc}) \text { for both oligo- and } \\
\text { multiple metastases. } 50 \text { patients with an overall } \\
125 \text { lesions. }\end{array}$ & $\begin{array}{l}\text { LC rate of } 94 \% \text {. Very low toxicity ( } 2 \% \text { risk of grade- } 3 \\
\text { toxicity). Improved median survival and PFS in } \\
\text { comparison to contemporary standards of care. }\end{array}$ \\
\hline Joyner et al. [59] & $\begin{array}{l}\text { Utilized SABR }(12 \mathrm{~Gy} \times 3 \mathrm{Fc}) \text { to assess feasibility } \\
\text { for centrally located lung metastases in } 8 \text { patients. }\end{array}$ & $\begin{array}{l}\text { All lesions confirmed locally controlled by PET/CT at } \\
\text { median follow-up of } 10.6 \text { months. All lesions confirmed } \\
\text { as locally controlled. }\end{array}$ \\
\hline Zhang et al. [60] & $\begin{array}{l}\text { Retrospective review of } 71 \text { patients treated with } \\
\text { SABR (dose range of 30-60 Gy in 2-12 fractions). }\end{array}$ & $\begin{array}{l}\text { 1- and } 5 \text {-year LC at } 88.8 \% \text { and } 75.4 \% \text {. No grade- } 3 \\
\text { toxicities. }\end{array}$ \\
\hline Rusthoven et al. [57] & $\begin{array}{l}\text { Assessed safety and efficacy of high-dose SABR } \\
(20 \mathrm{~Gy} \times 3 \mathrm{Fc}) \text {. }\end{array}$ & $\begin{array}{l}\text { Local control of } 100 \% \text { and } 96 \% \text {, at } 1 \text { and } 2 \text { years, } \\
\text { respectively. Low incidence of toxicity ( } 8 \% \text { grade- } 3 \text { and } \\
0 \% \text { grade- } 4 \text { ). }\end{array}$ \\
\hline Norihisa et al. [58] & $\begin{array}{l}\text { Retrospective analysis. } 34 \text { patients of lung } \\
\text { oligometastases treated with SABR with } 12 \mathrm{~Gy} \\
\text { fractions ( } 48 \mathrm{~Gy} \text { in } 18 \text { patients and } 60 \mathrm{~Gy} \text { in } 16 \\
\text { patients). }\end{array}$ & $\begin{array}{l}2 \text { year OS of } 84.3 \% \text {, and LC of } 90 \% \text {. No incidence of } \\
\text { local progression among the } 16 \text { patients treated with } \\
60 \text { Gy. SABR results comparable to surgical } \\
\text { metastasectomy. }\end{array}$ \\
\hline
\end{tabular}

PET-CT: positron emission tomography—computed tomography; PFS: progression free survival; LC: local control; Fc: fraction.

nodal oligometastases, the results with small series are very encouraging. Bae et al. treated 18 patients of abdominal lymph-nodal oligometastases. The 5-year local control rates were impressive at 57\% [61]. Choi et al. reported a retrospective analysis which involves 30 patients of gynecological malignancies with isolated para-aortic nodal recurrences treated with SABR. The 4-year local control rate was $67.4 \%$, and the median time to disease progression was 32 months [62]. Bignardi et al. studied 19 patients with retroperitoneal lymph nodal disease treated with SABR. The 2-year local control rate was about $78 \%$. Though it was observed that most patients eventually show progressive disease at other sites, the local control can bestow significant duration of quality of life [63]. Jereczek-Fossa et al. treated 14 patients of prostate cancer with isolated lymph nodal metastases with
SABR. While disease progression occurred at a mean time of 12.7 months, it was observed that no patients had in-field progression [64]. An outline of important trials evaluating the use of SABR for oligometastatic lymph nodal disease is provided in Table 5.

Of late, the use of SABR for adrenal metastases too has been attempted. The current studies have used a relatively low dose in comparison to SABR for other sites. Reasonable local control rates and no risk of severe toxicity have been reported (Table 6) $[65,66]$.

2.2. The Potential in Unresectable Malignancies. Surgery is the mainstay of care for malignancies such as the earlystage NSCLC (non-small cell lung cancer), HPB (hepatopancreaticobiliary), and RCC (renal cell carcinoma). However, 
TABLE 5: Evidence for the use of SABR in lymph nodal oligometastases.

\begin{tabular}{lll}
\hline Study & Remarks & Conclusions \\
\hline Bae et al. [61] & $\begin{array}{l}\text { SABR for 18 patients of abdominal LN } \\
\text { oligometastasis. }\end{array}$ & 5-year LC 57\%. \\
\hline Choi et al. [62] & $\begin{array}{l}\text { Retrospective }(n=30) \text {. SABR for isolated } \\
\text { para-aortic LN recurrence from } \\
\text { gynecological malignancies. }\end{array}$ & $\begin{array}{l}\text { 4-year LC of 67.4\%. Median time to progression of 32 } \\
\text { months. }\end{array}$ \\
\hline Bignardi et al. [63] & $\begin{array}{l}\text { Retroperitoneal LN }(n=19) \\
\text { oligometastases treated with SABR. }\end{array}$ & $\begin{array}{l}\text { 2-year LC of 78\%. Most patients progress systemically, } \\
\text { but local control adds to quality of life. }\end{array}$ \\
\hline Jereczek-Fossa et al. [64] & $\begin{array}{l}\text { Prostate cancer }(n=14) \text { with isolated LN } \\
\text { metastases. }\end{array}$ & $\begin{array}{l}\text { SABR provided 100\% local control. Most patients } \\
\text { progressed at median time of 12.7 months, but no case } \\
\text { of in-field progression. }\end{array}$ \\
\hline
\end{tabular}

LN: lymph node; LC: local control.

TABLE 6: Evidence for the use of SABR in adrenal metastases.

\begin{tabular}{lll}
\hline Study & Remarks & Conclusions \\
\hline Torok et al. [65] & $\begin{array}{l}\text { Retrospective analysis of 9 adrenal metastases } \\
\text { treated with SABR }(16 \mathrm{~Gy} \times 1 \mathrm{Fc} \text { or } 8-12 \mathrm{~Gy} \times 3 \mathrm{Fc}) .\end{array}$ & $\begin{array}{l}\text { Observed 1 complete response, 2 partial responses, and } \\
5 \text { stable lesions. Only one progressive lesion. Safety } \\
\text { established with no grade-3/4 toxicities. }\end{array}$ \\
\hline Scorsetti et al. [66] & $\begin{array}{l}\text { Prospective study of 34 patients with adrenal } \\
\text { metastases to assess tolerability and clinical } \\
\text { outcomes. }\end{array}$ & $\begin{array}{l}\text { LC of 66\% and 32\%, at 1 and 2 years, respectively. No } \\
\text { incidence of grade } \geq 3 \text { toxicity. }\end{array}$ \\
\hline
\end{tabular}

Fc: fraction; LC: local control.

surgery is not always feasible even among the $\mathrm{T}_{1} \mathrm{~N}_{0}$ and $\mathrm{T}_{2} \mathrm{~N}_{0}$ NSCLC, due to frequent comorbidities such as chronic obstructive pulmonary disease (COPD), cardiopulmonary insufficiencies, and, often, patient refusal $[67,68]$. The use of standard fractionation RT to a dose of 60-66 Gy, even when combined with concurrent chemotherapy, has not offered durable responses [69].

SABR has been used in early stage NSCLC who were inoperable and has been shown to yield benefits comparable to surgery. It may be observed that SABR is not associated with a significant risk of immediate mortality unlike thoracic surgery. Also, the local control rates are excellent, consistently exceeding $95 \%$ at 1 year, and median overall-survival consistently exceeds 5 years. SABR is now being tested by a number of trials for operable lung cancers too. An outline of the recent trials addressing the use of SABR in early stage NSCLC is provided in Table 7 [70-75].

Hepatobiliary and pancreatic malignancies too require surgical resection as a part of radical management. However, various factors preclude operability, with less than $20-30 \%$ of these patients being operable at presentation. The use of contemporary management with chemotherapy and conventionally fractionated RT has only offered modest benefits in term of local control or survival $[76,77]$. In hepatocellular carcinoma, SABR has been used in various settings and has demonstrated validity as a modality to prevent progression among patients awaiting definitive liver-transplantation, after nonresponse with chemoembolization and with a modified fractionation for patients with Child-Turcotte-Pugh Class B patients. An outline of these trials is provided in Table 8 [7882]. The use of SABR in pancreatic cancer has been attempted with success either definitively in the case of inoperability, in combination with sequential gemcitabine chemotherapy, or as an adjuvant treatment after surgery with a close/positive margin (Table 9) [83-87].

Renal cell carcinoma (RCC) has traditionally been regarded as radioresistant. While RCC indeed is poorly responsive to conventionally fractionated RT, it is now being realized that hypofractionated RT delivering high doses per fraction could induce radiosensitivity. It is hypothesized that the delivery of higher doses per fraction activates the ceramide-pathway which in turn induces radiosensitivity in the otherwise radioresistant RCC. Further, the abscopal effect due to immunological mechanisms could add to the systemic disease control in combination with targeted drugs [88]. Wersäll et al. studied patients of metastatic and inoperable RCC treated with SABR. The observed local control rate was very high, at 90-98\%. The benefit was higher for patients with three or less metastases [89]. Beitler et al. compiled a report describing the results with SABR for patients of RCC who refused definitive surgery. The nine patients were treated with $40 \mathrm{~Gy}$ in 5 fractions. At a median follow-up of 26.7 months, 4 of these 9 patients were alive. Since the 4 surviving patients have a follow-up duration of at least 4 years, the investigators concluded that hypofractionated radiotherapy could have a curative potential in organ confined RCC who could be inoperable for any reason [90]. Svedman et al. studied 7 patients of RCC within a single functioning kidney treated with $30 \mathrm{~Gy}$ in 3 fractions. Only one patient failed locally after a follow-up duration of 54 months [91]. Siva et al. have published a systematic review of the use of SABR for primary RCC with regards to local control and toxicity. They included three-prospective and seven-retrospective studies in the analysis. They derived a local control rate of about $93.9 \%$, 
TABLE 7: Trials using SABR for early stage lung cancers.

\begin{tabular}{lll}
\hline Trial & Remarks & Outcome \\
\hline Lagerwaard et al. [70] & $\begin{array}{l}\text { SABR (60 Gy in 3, 5, or 8 fractions depending on } \\
\text { tumour size and location) in potentially operable } \\
\text { patients. }\end{array}$ & $\begin{array}{l}\text { LC at 1 and 3 years were 98\% and 93\%, respectively. Less } \\
\text { than 3\% risk of grade 3 toxicity. Median OS exceeded 5 } \\
\text { years. 30-day postprocedure mortality was 0\%. }\end{array}$ \\
\hline Chan et al. [71] & $\begin{array}{l}\text { 16 stage-1 NSCLC medically inoperable with a } \\
\text { median age of 82 years. }\end{array}$ & $\begin{array}{l}\text { 2-year LC, DFS, and OS were 91\%, 71\%, and 87\%, } \\
\text { respectively. }\end{array}$ \\
\hline Haasbeek et al. [72] & $\begin{array}{l}\text { SABR (at 7.5 Gy } \times \text { 8 Fc) for centrally located early } \\
\text { NSCLC. }\end{array}$ & $\begin{array}{l}\text { Distant metastases and comorbidities were the } \\
\text { predominant cause of death. 3-year LC and OS rates } \\
\text { were 90.2\% and 51.1, respectively. }\end{array}$ \\
\hline Fakiris et al. [73] & $\begin{array}{l}\text { Phase-2 prospective trial involving 70 early staged } \\
\text { NSCLC treated with SABR (60-66 Gy). }\end{array}$ & $\begin{array}{l}\text { SABR results in high rates of local control in medically } \\
\text { inoperable patients of early NSCLC. Cancer specific } \\
\text { survival at 3 years was 81.7\%. }\end{array}$ \\
\hline Bilal et al. [74] & $\begin{array}{l}\text { Compared SABR and RFA for early stage } \\
\text { inoperable NSCLC. }\end{array}$ & $\begin{array}{l}\text { 5-year OS was higher in SABR (47\%) than RFA (27\%). } \\
\text { Timmerman et al. [75] }\end{array}$ \\
$\begin{array}{l}\text { Phase-2 prospective trial of Early stage NSCLC } \\
\text { who were medically inoperable treated with SABR } \\
\text { (18 Gy } \times \text { 3 Fc). }\end{array}$ & 3-year DFS and OS were 48.3\% and 55.8\%, respectively.
\end{tabular}

LC: local control; NSCLC: non-small cell lung carcinoma; DFS: disease free survival; OS: overall survival; RFA: radiofrequency ablation; Fc: fraction.

TABLE 8: Trials using SABR for inoperable hepatic cancers.

\begin{tabular}{|c|c|c|}
\hline Trial & Remarks & Outcome \\
\hline Kang et al. [78] & $\begin{array}{l}\text { Phase- } 2 \text { prospective trial using SABR (upto } 20 \mathrm{~Gy} \times \\
3 \mathrm{Fc} \text { ) for inoperable } \mathrm{HCC} \text { as a local salvage after } \\
\text { incomplete transarterial chemoembolization in } 50 \\
\text { patients. }\end{array}$ & $\begin{array}{l}\text { Complete response and partial response rates were } \\
38.3 \% \text { and } 38.3 \% \text { each. At } 2 \text { years, the LC, OS, and PFS } \\
\text { were } 94.6 \%, 68.7 \% \text {, and } 33.8 \% \text {, respectively. The toxicity } \\
\text { rates were } 6.4 \% \text { and } 4.3 \% \text { for grade- } 3 \text { and } 4 \text { toxicity. } \\
\text { Demonstrated feasibility of SBRT after incomplete } \\
\text { TACE for inoperable HCC. }\end{array}$ \\
\hline O'Connor et al. [79] & $\begin{array}{l}10 \text { patients were given SABR (mean dose } 51 \mathrm{~Gy} \text { in } 3 \mathrm{Fc} \text { ) } \\
\text { during wait for definitive transplantation. }\end{array}$ & $\begin{array}{l}\text { Post-SABR excision revealed a complete response rate } \\
\text { of } 27 \% \text {. There was no progression in any case which had } \\
\text { not attained complete response. SABR prevents } \\
\text { progression in patients of HCC awaiting definitive } \\
\text { transplantation. }\end{array}$ \\
\hline Andolino et al. [80] & $\begin{array}{l}60 \text { patients with HCC treated with SABR (doses of } \\
14 \mathrm{~Gy} \times 3 \mathrm{Fc} \text { for patients with Child-Turcotte-Pugh } \\
\text { Class A; } 8 \mathrm{~Gy} \times 5 \mathrm{Fc} \text { for Class B). }\end{array}$ & $\begin{array}{l}\text { 2-year LC, PFS, and OS were } 90 \%, 48 \% \text {, and } 67 \% \text {, } \\
\text { respectively. } 23 \text { patients underwent transplantation } \\
\text { subsequently. Concluded that SABR is a safe, effective, } \\
\text { and noninvasive option for patients with HCC }<6 \mathrm{~cm} \text {. }\end{array}$ \\
\hline Ibarra et al. [81] & $\begin{array}{l}21 \text { HCC and } 11 \text { intrahepatic cholangiocarcinoma treated } \\
\text { with SABR. }\end{array}$ & $\begin{array}{l}\text { Overall freedom from local progression was } 63 \% \text { at a } \\
\text { median follow-up at } 12.9 \text { months. Low overall toxicity. }\end{array}$ \\
\hline Sandroussi et al. [82] & $\begin{array}{l}\text { Assessed use of SABR as a bridge to transplantation in } \\
10 \text { HCC patients using personalized dose-fractionation } \\
\text { to spare uninvolved liver, while preventing progression } \\
\text { of HCC. }\end{array}$ & $\begin{array}{l}\text { No treated lesion progressed after treatment and, hence, } \\
\text { SABR can be considered as an effective bridge to } \\
\text { hepatic transplantation, for patients on waiting lists for } \\
\text { subsequent hepatic transplantation. }\end{array}$ \\
\hline
\end{tabular}

HCC: hepatocellular carcinoma; TACE: transarterial chemoembolization; LC: local control; OS: overall survival; PFS: progression free survival; Fc: fraction.

and a severe toxicity (grade- 3 or higher) rate of $3.8 \%$. They did conclude that while there was promising rates of local control, there was a need for accumulating more evidence for reaching at a consensus regarding the ideal dose-fractionation for treatment of primary RCC in medically inoperable patients [92] (Table 10).

2.3. The Potential in Reirradiation. The outcome of patients with local recurrence of malignancy within an area already treated with full dose of radiation is often dismal. The reuse of RT is often limited by the previous dose and the duration between previous irradiation and relapse. It is seldom possible to use a full tumoricidal dose with conventional techniques to achieve local control $[93,94]$. Recently, there has been considerable interest in the use of SABR for reirradiation in patients with prior history of radiotherapy (Table 11).

In head and neck malignancies, where RT is a prime treatment modality, a dose with curative intent is most often delivered to the primary and nodal areas. In cases of recurrence, as in nasopharyngeal cancers, the use of surgery 
TABLE 9: Trials using SABR for pancreaticobiliary cancers.

\begin{tabular}{lll}
\hline Trial & Remarks & Outcome \\
\hline Chang et al. [83] & $\begin{array}{l}77 \text { patients with unresectable pancreatic cancer } \\
\text { treated with SABR }(25 \mathrm{~Gy} \times 1 \mathrm{FC}) .\end{array}$ & $\begin{array}{l}\text { Effective for LC. Should be used with rigorous quality } \\
\text { assurance to reduce complications. Distant metastases } \\
\text { account for the vast majority of mortality. }\end{array}$ \\
\hline Rwigema et al. [84] & $\begin{array}{l}\text { 24 patients treated with SABR adjuvantly after } \\
\text { surgical resection. }\end{array}$ & $\begin{array}{l}\text { Freedom from local progression was 66\% at one year } \\
\text { and median OS was 26.7 months. No incidence of grade } \\
\text { 3 or 4 toxicity. Shorter treatment course allowed timely } \\
\text { initiation of systemic chemotherapy. }\end{array}$ \\
\hline Schellenberg et al. [85] & $\begin{array}{l}\text { Phase-2 trial evaluated LC and OS in patients treated } \\
\text { with sequential gemcitabine and SABR (25 Gy } \times \\
1 \text { Fc). }\end{array}$ & $\begin{array}{l}\text { Freedom from local progression was 94\% at 1 year. } \\
\text { 1-year survival was 50\% (mortalities being mainly from } \\
\text { distant metastases). }\end{array}$ \\
\hline Barney et al. [86] & $\begin{array}{l}12 \text { unresectable primary and recurrent } \\
\text { cholangiocarcinoma lesions treated with SABR } \\
\text { (median dose 55 Gy). }\end{array}$ & $\begin{array}{l}\text { Freedom from progression within treated volumes was } \\
100 \% \text {. OS remained unchanged due to progression } \\
\text { elsewhere. }\end{array}$ \\
\hline $\begin{array}{l}\text { 10 patients with unresectable hilar- } \\
\text { cholangiocarcinoma treated with SABR (10 Gy } \times \\
3 \text { Fc) and gemcitabine. }\end{array}$ & $\begin{array}{l}\text { 2-year and 4-year survival were 80\% and 30\%, } \\
\text { respectively. }\end{array}$ \\
\hline
\end{tabular}

Fc: fraction; OS: overall survival; LC: local control.

TABLE 10: Trials using SABR for renal cell carcinoma.

\begin{tabular}{lll}
\hline Trial & Remarks & Outcome \\
\hline Wersäll et al. [89] & SABR for inoperable or metastatic RCC. & $\begin{array}{l}\text { 90-98\% local control rate. Higher benefit for patients } \\
\text { with } \leq 3 \text { metastases. }\end{array}$ \\
\hline Beitler et al. [90] & $\begin{array}{l}\text { 9 RCC patients (confined to kidney) refusing } \\
\text { surgery. SABR 40 Gy in 5 Fc. }\end{array}$ & $\begin{array}{l}\text { 4 of 9 patients alive at median follow-up of 26.7 } \\
\text { months. Curative potential of SABR in organ confined } \\
\text { RCC established. }\end{array}$ \\
\hline Svedman et al. [91] & $\begin{array}{l}\text { 7 RCC patients with single functioning kidney. } \\
\text { SABR 30 Gy in 3 Fc. }\end{array}$ & $\begin{array}{l}\text { Only 1 of 7 patients failed locally at follow-up of 54 } \\
\text { months. }\end{array}$ \\
\hline Siva et al. [92] & $\begin{array}{l}\text { Systematic review of 3 prospective and 7 } \\
\text { retrospective studies on use of SABR for primary } \\
\text { RCC. }\end{array}$ & $\begin{array}{l}\text { Derived LC rate of 93.9\% and rate of severe toxicity } \\
\text { (grade-3 or higher) of 3.8\%. }\end{array}$ \\
\hline
\end{tabular}

LC: local control; RCC: renal cell carcinoma; Fc: fraction.

for salvage is often fraught with anatomical limitations and serious risk of morbidities. Ozyigit et al. compared the outcomes of SABR versus the use of 3DCRT (three-dimensional conformal radiotherapy) with or without brachytherapy for reirradiation after local relapse in patients with nasopharyngeal carcinoma [95]. The observed response rates with the two approaches were similar, however, with much lower rates of toxicities among patients treated with SABR. Iwata et al. reported on the feasibility of SABR for salvage of post$\mathrm{RT}$ recurrence in sinonasal malignancies [96]. In general, SABR may have an important role in the reirradiation of head and neck malignancies given the high conformality and the ability to spare critical structures such as the brain and the spinal cord. Additionally, the lower overall treatment times associated with SABR may add further benefits from the QOL point of view.

The preferred treatment for an in-field recurrence after previous full dose radiotherapy for abdominal and pelvic malignancies would call for surgical resection. However, surgery is not often feasible given the associated morbidities expectable with resections, with disease often situated to critical structures such as the iliac blood vessels. Again, SABR for reirradiation has a potential for eradication/long term control of postradiation in-field recurrences in abdominal and pelvic malignancies [64, 95-97].

Spinal column metastases are very frequently treated with conventional radiotherapy for palliation of pain and spinal cord compression, many times in conjunction with decompressive stabilizing surgery. Commonly used doses for conventional radiotherapy in the palliation of spinal metastases include $8 \mathrm{~Gy}$ in a single fraction to $40 \mathrm{~Gy}$ in 20 fractions and various intermediate schedules. Though conventional RT provides good pain relief, the duration of pain control is generally low, in the range of 3-6 months. On eventual resurgence of pain, the use of further conventional RT is generally avoided in view of the risk of spinal cord toxicity. The ability of image-guided and intensity modulated SABR to spare the spinal cord has recently gained considerable interest. Sahgal et al. in their series used SABR both in patients with no prior radiation (23 patients) and in those with history of prior conventional irradiation (37 patients). With the use of a median dose of $24 \mathrm{~Gy}$ in 3 fractions, the overall 2-year progression free probability was as high as $85 \%$. Importantly, it was observed that there was no significant 
TABLE 11: SABR for reirradiation for relapse after previous irradiation.

\begin{tabular}{|c|c|c|c|}
\hline Trial & Site & Method & Result \\
\hline Ozyigit et al. [95] & Nasopharynx & $\begin{array}{l}\text { Retrospectively compared outcomes of } \\
\text { SABR versus 3DCRT }+/- \\
\text { brachytherapy. }\end{array}$ & $\begin{array}{l}\text { Responses were similar in both arms. However, } \\
\text { SABR associated with lesser toxicity. }\end{array}$ \\
\hline Iwata et al. [96] & Sinonasal & $\begin{array}{l}51 \text { patients of post-RT recurrent } \\
\text { sinonasal malignancies reirradiated } \\
\text { with SABR (median dose } 60 \mathrm{~Gy} \text { ). }\end{array}$ & $\begin{array}{l}\text { Feasible for salvage post-RT. Further innovations } \\
\text { needed in fractionation and combination } \\
\text { chemotherapy. }\end{array}$ \\
\hline $\begin{array}{l}\text { Jereczek-Fossa et } \\
\text { al. [64] }\end{array}$ & $\begin{array}{l}\text { Prostate primary or } \\
\text { nodal }\end{array}$ & $\begin{array}{l}\text { SABR (median dose of } 30 \mathrm{~Gy} \text { in } 4-5 \mathrm{Fc} \text { ) } \\
\text { for reirradiation in } 34 \text { patients. }\end{array}$ & $\begin{array}{l}\text { Feasible approach for isolated recurrent } \\
\text { primary/nodal prostate cancer. Low toxicity. } \\
\text { In-field progression in }<10 \% \text { cases. }\end{array}$ \\
\hline Dewas et al. [97] & Uterocervical, bladder & $\begin{array}{l}16 \text { patients treated with SABR }(6 \times \\
6 \mathrm{Fc}) \text { for reirradiation of lateral pelvic } \\
\text { recurrences. }\end{array}$ & $\begin{array}{l}\text { Offers a short and well-tolerated treatment for } \\
\text { lateral pelvic recurrences in previously irradiated } \\
\text { patients who are otherwise not treatable. }\end{array}$ \\
\hline Sahgal et al. [98] & Spine & $\begin{array}{l}37 \text { patients with history of prior } \\
\text { conventional RT and } 23 \text { patients with } \\
\text { no prior history of RT. Reirradiation } \\
\text { with SABR (median dose of } 24 \mathrm{~Gy} \text { in } \\
3 \mathrm{Fc} \text { ). }\end{array}$ & $\begin{array}{l}\text { 2-year overall progression free probability was } \\
85 \% \text {. No significant difference in survival or local } \\
\text { control in patients with or without prior } \\
\text { radiotherapy. }\end{array}$ \\
\hline Choi et al. [99] & Spine & $\begin{array}{l}\text { Retrospective series }(n=42) \text {. SABR } \\
\text { after prior conventional RT. }\end{array}$ & $\begin{array}{l}\text { Reirradiation with SABR provided 1-year LC of } \\
73 \% \text {. Time interval between prior RT and SABR } \\
\text { was predictive of response. }\end{array}$ \\
\hline Sterzing et al. [100] & Spine & $N=36 . \mathrm{SABR}$ after prior RT. & 2-year LC of $63 \%$. No incidence of severe toxicity. \\
\hline $\begin{array}{l}\text { Poltinnikov et al. } \\
{[106]}\end{array}$ & Lung & $\begin{array}{l}17 \text { NSCLC patients all recurred after } \\
\text { prior conventional RT of } \geq 50 \mathrm{~Gy} \text {. }\end{array}$ & $\begin{array}{l}\text { SABR provided median OS of } 5.5 \text { months. } 11 \text { of } 13 \\
\text { patients who were symptomatic with dyspnoea } \\
\text { had improved. }\end{array}$ \\
\hline Kelly et al. [107] & Lung & $\begin{array}{l}\text { Retrospective study }(n=36) \text {. SABR on } \\
\text { relapse after prior thoracic RT. }\end{array}$ & $\begin{array}{l}\text { Excellent in-field tumor control of } 92 \% \text { at } 2 \text {-years. } \\
\text { No grade } 4-5 \text { toxicities. }\end{array}$ \\
\hline Coon et al. [108] & Lung & $\begin{array}{l}\text { SABR for recurrent primary lung } \\
\text { lesions after prior RT }(n=12) \text {. }\end{array}$ & 1 -year LC was $92 \%$, and 1-year OS was $67 \%$. \\
\hline
\end{tabular}

3DCRT: three-dimensional conformal radiotherapy; Fc: fraction; LC: local control; OS: overall survival.

difference in overall survival or progression free probability among patients being treated with SABR irrespective of whether they had been previously irradiated [98]. Choi et al. in their retrospective series of 42 patients reirradiated with SABR after prior RT noted a 1-year local control rate of $73 \%$. It was however noted that patients with a time to retreatment (time interval between prior radiotherapy and SABR) of $<12$ months was a significant predictor of local failure, with these patients having a 1-year local control rate of $58 \%$. One patient of these 42 patients developed grade- 4 neurotoxicity [99]. Sterzing et al. utilized SABR to treat 36 patients with prior history of RT. They recorded a 2 -year local control of $63 \%$, and no incidence of severe toxicity was observed [100]. Similar studies by Garg et al. and Chang et al. observed 1-year local control rates of $76 \%$ and $81 \%$ [101, 102]. Mahadevan et al. observed a median progression free survival of 9 months and that $65 \%$ of patients had pain relief on reirradiation with SABR [103].

Most patients diagnosed with unresectable NSCLC get treated with concurrent chemoradiotherapy. However, despite a degree of local control, up to $85 \%$ of patients subsequently suffer locoregional failures $[104,105]$. The proportion of patients undergoing reirradiation with conventional RT is very low because of concerns such as spinal cord, esophagus, pulmonary, and cardiac toxicities. Recently, SABR has been utilized for reirradiation with an intention to prolong local control while minimising radiation exposure to the spinal cord and esophagus. It must however be emphasized here that the ideal dose-fractionation schemes are unknown and may need to be tailored to the individual patient with regards to prior dose of radiation, duration between prior irradiation, proximity to other critical structures, and overall condition of the patient. Poltinnikov et al. described 17 patients of NSCLC being reirradiated with SABR. All patients had been treated previously to a dose of at least $50 \mathrm{~Gy}$. Though the median overall survival was just 5.5 months, it was remarkable that 11 of 13 patients who were symptomatic with shortness of breath had improved with SABR [106]. Studies by Kelly et al. and Coon et al. both observed 1-year local control rates of $92 \%$. The observed 1-year survival rates were $82 \%$ and $67 \%$, respectively $[107,108]$.

\section{Conclusions}

Despite the large volume of published evidence testifying the potential benefits with the use of SABR, its clinical adoption, particularly in developing countries remains low. It is attributable to various factors, ranging from a lack of awareness among clinicians, to a more serious therapeutic 
nihilism. While cost is often cited as a factor against SABR, it must be noted that the costs associated with a short course of SABR often is comparable in the overall costs of a protracted course of conventional RT which may easily extend to weeks in duration.

There is an urgent need for an initiative not just from oncologists, but also from the institutional administrations and industry as well as the governments. The investment involved in the procurement of a machine capable of SABR may be high, but from the tax-payer's point of view, it would be "money spent well." After all, we are fighting a "war on cancer." Countries across the world-those involved in actual military battles and those not involved in conflict-spend a large amount of funds upon expensive military hardware. Governments all around the world which speak about "war on cancer," in a hypocritical way neglect genuine spending directed towards the "war on cancer."

The cost of military war hardware is far more expensive in comparison to the hardware and software required for the "war on cancer." For an example, the average cost of a modern fighter-jet is US\$100-200 million per unit $[109,110]$. With the money required to buy a single modern fighter-jet, more than a dozen linear-accelerators capable of performing SABR can be installed.

Unless genuine action is taken by governments across the world to spend adequately upon making newer radiotherapy technologies to the masses, the "war on cancer" could be regarded as a "farce." May SABR be perceived as a basic necessity in our war on cancer, rather than being regarded as a luxury for some.

\section{Key Messages}

While conventionally fractionated radiotherapy and surgery in the treatment of oligometastatic disease may indeed achieve a degree of palliation, the local responses are often short-lived. Stereotactic ablative radiotherapy (SABR) offers local responses which have been durable, hence achieving long-term palliation in most, and cure in many.

\section{Conflict of Interests}

All authors declare that there is no conflict of interests.

\section{References}

[1] J. F. Fowler, W. A. Tomé, J. D. Fenwick, and M. P. Mehta, "A challenge to traditional radiation oncology," International Journal of Radiation Oncology, Biology, Physics, vol. 60, no. 4, pp. 1241-1256, 2004.

[2] J. F. Fowler, "21 years of biologically effective dose," British Journal of Radiology, vol. 83, no. 991, pp. 554-568, 2010.

[3] C. Park, L. Papiez, S. Zhang, M. Story, and R. D. Timmerman, "Universal survival curve and single fraction equivalent dose: useful tools in understanding potency of ablative radiotherapy," International Journal of Radiation Oncology Biology Physics, vol. 70, no. 3, pp. 847-852, 2008.

[4] H. D. Thames Jr., H. R. Withers, L. J. Peters, and G. H. Fletcher, "Changes in early and late radiation responses with altered dose fractionation: implications for dose-survival relationships," International Journal of Radiation Oncology Biology Physics, vol. 8, no. 2, pp. 219-226, 1982.

[5] B. Jones, L. T. Tan, and R. G. Dale, "Derivation of the optimum dose per fraction from the linear quadratic model," British Journal of Radiology, vol. 68, no. 812, pp. 894-902, 1995.

[6] J. F. Fowler, "Fractionated radiation therapy after Strandqvist," Acta Radiologica Oncology, vol. 23, no. 4, pp. 209-216, 1984.

[7] M. V. Williams, J. Denekamp, and J. F. Fowler, "A review of alpha/beta ratios for experimental tumors : implications for clinical studies of altered fractionation," International Journal of Radiation Oncology, Biology, Physics, vol. 11, pp. 87-96, 1985.

[8] E. H. Balagamwala, S. T. Chao, and J. H. Suh, "Principles of radiobiology of stereotactic radiosurgery and clinical applications in the central nervous system," Technology in Cancer Research and Treatment, vol. 11, no. 1, pp. 3-13, 2012.

[9] H. Blomgren, I. Lax, I. Naslund, and R. Svanstrom, "Stereotactic high dose fraction radiation therapy of extracranial tumors using an accelerator. Clinical experience of the first thirty-one patients," Acta Oncologica, vol. 34, no. 6, pp. 861-870, 1995.

[10] M. Ayadi, C. Ginestet, F. Gassa, L. Claude, and J.-J. Mazeron, "Linac-based stereotactic radiosurgery and radiotherapy," Bulletin du Cancer, vol. 97, no. 7, pp. 791-806, 2010.

[11] B. W. Loo, J. Y. Chang, L. A. Dawson et al., "Stereotactic ablative radiotherapy: what's in a name?" Practical Radiation Oncology, vol. 1, no. 1, pp. 38-39, 2011.

[12] K. R. Trott, "Experimental results and clinical implications of the four R's in fractionated radiotherapy," Radiation and Environmental Biophysics, vol. 20, no. 3, pp. 159-170, 1982.

[13] I. Corre, C. Niaudet, and F. Paris, "Plasma membrane signaling induced by ionizing radiation," Mutation Research-Reviews in Mutation Research, vol. 704, no. 1-3, pp. 61-67, 2010.

[14] Y. Lee, S. L. Auh, Y. Wang et al., "Therapeutic effects of ablative radiation on local tumor require $\mathrm{CD} 8^{+} \mathrm{T}$ cells: changing strategies for cancer treatment," Blood, vol. 114, no. 3, pp. 589-595, 2009.

[15] M. Y. Almaghrabi, S. Supiot, F. Paris, M.-A. Mahé, and E. Rio, "Stereotactic body radiation therapy for abdominal oligometastases: a biological and clinical review," Radiation Oncology, vol. 7, no. 1, article 126, 2012.

[16] S. E. Finkelstein, R. Timmerman, W. H. McBride et al., "The confluence of stereotactic ablative radiotherapy and tumor immunology," Clinical and Developmental Immunology, vol. 2011, Article ID 439752, 7 pages, 2011.

[17] S. S. Lo, A. J. Fakiris, E. L. Chang et al., "Stereotactic body radiation therapy: a novel treatment modality," Nature Reviews Clinical Oncology, vol. 7, no. 1, pp. 44-54, 2010.

[18] F. Pajonk, E. Vlashi, and W. H. McBride, "Radiation resistance of cancer stem cells: the 4 R's of radiobiology revisited," Stem Cells, vol. 28, no. 4, pp. 639-648, 2010.

[19] H. J. Park, R. J. Griffin, S. Hui, S. H. Levitt, and C. W. Song, "Radiation-induced vascular damage in tumors: implications of vascular damage in ablative hypofractionated radiotherapy (SBRT and SRS)," Radiation Research, vol. 177, no. 3, pp. 311-327, 2012.

[20] E. Touboul and M. Schlienger, "Radiotherapeutic basis of radiosurgery as applied to cerebral arteriovenous malformations: dose-volume effects," Neurochirurgie, vol. 47, no. 2-3, pp. 212220, 2001.

[21] M. Kocher, H. Treuer, J. Voges, M. Hoevels, V. Sturm, and R.-P. Müller, "Computer simulation of cytotoxic and vascular effects of radiosurgery in solid and necrotic brain metastases," Radiotherapy and Oncology, vol. 54, no. 2, pp. 149-156, 2000. 
[22] M. T. Milano, A. W. Katz, H. Zhang, and P. Okunieff, "Oligometastases treated with stereotactic body radiotherapy: longterm follow-up of prospective study," International Journal of Radiation Oncology, Biology, Physics, vol. 83, no. 3, pp. 878-886, 2012.

[23] M. T. Milano, A. W. Katz, A. G. Muhs et al., "A prospective pilot study of curative-intent stereotactic body radiation therapy in patients with 5 or fewer oligometastatic lesions," Cancer, vol. 112, no. 3, pp. 650-658, 2008.

[24] B. M. Künzli, P. Abitabile, and C. A. Maurer, "Radiofrequency ablation of liver tumors: actual limitations and potential solutions in the future," World Journal of Hepatology, vol. 3, no. 1, pp. 8-14, 2011.

[25] T. F. Wood, D. M. Rose, M. Chung, D. P. Allegra, L. J. Foshag, and A. J. Bilchik, "Radiofrequency ablation of 231 unresectable hepatic tumors: Indications, limitations, and complications," Annals of Surgical Oncology, vol. 7, no. 8, pp. 593-600, 2000.

[26] C. M. Faul and J. C. Flickinger, "The use of radiation in the management of spinal metastases," Journal of Neuro-Oncology, vol. 23, no. 2, pp. 149-161, 1995.

[27] Y. Yamada, M. H. Bilsky, D. M. Lovelock et al., "High-dose, single-fraction image-guided intensity-modulated radiotherapy for metastatic spinal lesions," International Journal of Radiation Oncology, Biology, Physics, vol. 71, no. 2, pp. 484-490, 2008.

[28] E. L. Chang, A. S. Shiu, E. Mendel et al., "Phase I/II study of stereotactic body radiotherapy for spinal metastasis and its pattern of failure," Journal of Neurosurgery: Spine, vol. 7, no. 2, pp. 151-160, 2007.

[29] B. Gill, E. Oermann, A. Ju et al., "Fiducial-free CyberKnife stereotactic body radiation therapy for single vertebral body metastases: acceptable local control and normal tissue tolerance with five-fraction approach," Frontiers in Oncology, vol. 2, article 39, 2012.

[30] R. J. Amdur, J. Bennett, K. Olivier et al., "A Prospective, phase II study demonstrating the potential value and limitation of radiosurgery for spine metastases," The American Journal of Clinical Oncology, vol. 32, no. 5, pp. 515-520, 2009.

[31] S. Ryu, R. Jin, J.-Y. Jin et al., "Pain control by image-guided radiosurgery for solitary spinal metastasis," Journal of Pain and Symptom Management, vol. 35, no. 3, pp. 292-298, 2008.

[32] S. Ryu, S. L. Pugh, P. C. Gerszten et al., "RTOG 0631 phase 2/3 study of image guided stereotactic radiosurgery for localized (1-3) spine metastases: phase 2 results," Practical Radiation Oncology, vol. 4, no. 2, pp. 76-81, 2014.

[33] P. C. Gerszten, S. A. Burton, C. Ozhasoglu, and W. C. Welch, "Radiosurgery for spinal metastases: clinical experience in 500 cases from a single institution," Spine, vol. 32, no. 2, pp. 193-199, 2007.

[34] S. Milker-Zabel, A. Zabel, C. Thilmann, W. Schlegel, M. Wannenmacher, and J. Debus, "Clinical results of retreatment of vertebral bone metastases by stereotactic conformal radiotherapy and intensity-modulated radiotherapy," International Journal of Radiation Oncology, Biology, Physics, vol. 55, no. 1, pp. 162-167, 2003.

[35] H. D. Moulding, J. B. Elder, E. Lis et al., "Local disease control after decompressive surgery and adjuvant high-dose singlefraction radiosurgery for spine metastases," Journal of Neurosurgery: Spine, vol. 13, no. 1, pp. 87-93, 2010.

[36] S. Sohn and C. K. Chung, "The role of stereotactic radiosurgery in metastasis to the spine," Journal of Korean Neurosurgical Society, vol. 51, no. 1, pp. 1-7, 2012.
[37] M. E. Linskey, D. W. Andrews, A. L. Asher et al., "The role of stereotactic radiosurgery in the management of patients with newly diagnosed brain metastases: a systematic review and evidence-based clinical practice guideline," Journal of NeuroOncology, vol. 96, no. 1, pp. 45-68, 2010.

[38] C. G. Patil, K. Pricola, J. M. Sarmiento, S. K. Garg, A. Bryant, and K. L. Black, "Whole brain radiation therapy (WBRT) alone versus WBRT and radiosurgery for the treatment of brain metastases," Cochrane Database of Systematic Reviews, vol. 9, Article ID CD006121, 2012.

[39] D. W. Andrews, C. B. Scott, P. W. Sperduto et al., "Whole brain radiation therapy with or without stereotactic radiosurgery boost for patients with one to three brain metastases: phase III results of the RTOG 9508 randomised trial," The Lancet, vol. 363, no. 9422, pp. 1665-1672, 2004.

[40] H. Aoyama, H. Shirato, M. Tago et al., "Stereotactic radiosurgery plus whole-brain radiation therapy vs stereotactic radiosurgery alone for treatment of brain metastases: a randomized controlled trial," Journal of the American Medical Association, vol. 295, no. 21, pp. 2483-2491, 2006.

[41] M. Kocher, R. Soffietti, U. Abacioglu et al., "Adjuvant wholebrain radiotherapy versus observation after radiosurgery or surgical resection of one to three cerebral metastases: results of the EORTC 22952-26001 study," Journal of Clinical Oncology, vol. 29, no. 2, pp. 134-141, 2011.

[42] M. Yamamoto, T. Serizawa, T. Shuto et al., "Stereotactic radiosurgery for patients with multiple brain metastases (JLGK0901): a multi-institutional prospective observational study," The Lancet Oncology, vol. 15, no. 4, pp. 387-395, 2014.

[43] E. L. Chang, J. S. Wefel, K. R. Hess et al., "Neurocognition in patients with brain metastases treated with radiosurgery or radiosurgery plus whole-brain irradiation: a randomised controlled trial," The Lancet Oncology, vol. 10, no. 11, pp. 1037-1044, 2009.

[44] G. S. Gazelle, M. G. M. Hunink, K. M. Kuntz et al., "Cost-effectiveness of hepatic metastasectomy in patients with metastatic colorectal carcinoma: a state-transition Monte Carlo decision analysis," Annals of Surgery, vol. 237, no. 4, pp. 544-555, 2003.

[45] J. Scheele and A. Altendorf-Hofmann, "Resection of colorectal liver metastases," Langenbeck's Archives of Surgery, vol. 384, no. 4, pp. 313-327, 1999.

[46] R. T.-P. Poon, S.-T. Fan, F. H.-F. Tsang, and J. Wong, "Locoregional therapies for hepatocellular carcinoma: a critical review from the surgeon's perspective," Annals of Surgery, vol. 235, no. 4, pp. 466-486, 2002.

[47] D. Ansari and R. Andersson, "Radiofrequency ablation or percutaneous ethanol injection for the treatment of liver tumors," World Journal of Gastroenterology, vol. 18, no. 10, pp. 1003-1008, 2012.

[48] G. Germani, M. Pleguezuelo, K. Gurusamy, T. Meyer, G. Isgrò, and A. K. Burroughs, "Clinical outcomes of radiofrequency ablation, percutaneous alcohol and acetic acid injection for hepatocelullar carcinoma: a meta-analysis," Journal of Hepatology, vol. 52, no. 3, pp. 380-388, 2010.

[49] A. Townsend, T. Price, and C. Karapetis, "Selective internal radiation therapy for liver metastases from colorectal cancer," Cochrane Database of Systematic Reviews, vol. 4, Article ID CD007045, 2009.

[50] K. E. Rusthoven, B. D. Kavanagh, H. Cardenes et al., "Multiinstitutional phase I/II trial of stereotactic body radiation therapy for liver metastases," Journal of Clinical Oncology, vol. 27, no. 10, pp. 1572-1578, 2009. 
[51] R. Lanciano, J. Lamond, J. Yang et al., "Stereotactic body radiation therapy for patients with heavily pretreated liver metastases and liver tumors," Frontiers in Oncology, vol. 2, article 23, 2012.

[52] G. Ambrosino, F. Polistina, G. Costantin et al., "Image-guided robotic stereotactic radiosurgery for unresectable liver metastases: preliminary results," Anticancer Research, vol. 29, no. 8, pp. 3381-3384, 2009.

[53] M. T. Lee, J. J. Kim, R. Dinniwell et al., "Phase I study of individualized stereotactic body radiotherapy of liver metastases," Journal of Clinical Oncology, vol. 27, no. 10, pp. 1585-1591, 2009.

[54] A. W. Katz, M. Carey-Sampson, A. G. Muhs, M. T. Milano, M. C. Schell, and P. Okunieff, "Hypofractionated stereotactic body radiation therapy (SBRT) for limited hepatic metastases," International Journal of Radiation Oncology Biology Physics, vol. 67, no. 3, pp. 793-798, 2007.

[55] A. E. M. van der Pool, A. M. Romero, W. Wunderink et al., "Stereotactic body radiation therapy for colorectal liver metastases," British Journal of Surgery, vol. 97, no. 3, pp. 377-382, 2010.

[56] P. Okunieff, A. L. Petersen, A. Philip et al., "Stereotactic Body Radiation Therapy (SBRT) for lung metastases," Acta Oncologica, vol. 45, no. 7, pp. 808-817, 2006.

[57] K. E. Rusthoven, B. D. Kavanagh, S. H. Burri et al., "Multiinstitutional phase I/II trial of stereotactic body radiation therapy for lung metastases," Journal of Clinical Oncology, vol. 27, no. 10, pp. 1579-1584, 2009.

[58] Y. Norihisa, Y. Nagata, K. Takayama et al., "Stereotactic body radiotherapy for oligometastatic lung tumors," International Journal of Radiation Oncology Biology Physics, vol. 72, no. 2, pp. 398-403, 2008.

[59] M. Joyner, B. J. Salter, N. Papanikolaou, and M. Fuss, "Stereotactic body radiation therapy for centrally located lung lesions," Acta Oncologica, vol. 45, no. 7, pp. 802-807, 2006.

[60] Y. Zhang, J. P. Xiao, H. Z. Zhang et al., "Stereotactic body radiation therapy favors long-term overall survival in patients with lung metastases: five-year experience of a single-institution," Chinese Medical Journal, vol. 124, no. 24, pp. 4132-4137, 2011.

[61] S. H. Bae, M.-S. Kim, C. K. Cho et al., "High dose stereotactic body radiotherapy using three fractions for colorectal oligometastases," Journal of Surgical Oncology, vol. 106, no. 2, pp. 138-143, 2012.

[62] C. W. Choi, C. K. Cho, S. Y. Yoo et al., "Image-guided stereotactic body radiation therapy in patients with isolated para aortic lymph node metastases from uterine cervical and corpus cancer," International Journal of Radiation Oncology Biology Physics, vol. 74, no. 1, pp. 147-153, 2009.

[63] M. Bignardi, P. Navarria, P. Mancosu et al., "Clinical outcome of hypofractionated stereotactic radiotherapy for abdominal lymph node metastases," International Journal of Radiation Oncology Biology Physics, vol. 81, no. 3, pp. 831-838, 2011.

[64] B. A. Jereczek-Fossa, G. Beltramo, L. Fariselli et al., "Robotic image-guided stereotactic radiotherapy, for isolated recurrent primary, lymph node or metastatic prostate cancer," International Journal of Radiation Oncology, Biology, Physics, vol. 82, no. 2, pp. 889-897, 2012.

[65] J.Torok, R. E. Wegner, S. A. Burton, and D. E. Heron, "Stereotactic body radiation therapy for adrenal metastases: a retrospective review of a noninvasive therapeutic strategy," Future Oncology, vol. 7, no. 1, pp. 145-151, 2011.

[66] M. Scorsetti, F. Alongi, A. R. Filippi et al., "Long-term local control achieved after hypofractionated stereotactic body radiotherapy for adrenal gland metastases: a retrospective analysis of 34 patients," Acta Oncologica, vol. 51, no. 5, pp. 618-623, 2012.
[67] S. Cykert, P. Dilworth-Anderson, M. H. Monroe et al., "Factors associated with decisions to undergo surgery among patients with newly diagnosed early-stage lung cancer," Journal of the American Medical Association, vol. 303, no. 23, pp. 2368-2376, 2010.

[68] Ö. Birim, A. P. Kappetein, and A. J. J. C. Bogers, "Charlson comorbidity index as a predictor of long-term outcome after surgery for nonsmall cell lung cancer," European Journal of Cardio-thoracic Surgery, vol. 28, no. 5, pp. 759-762, 2005.

[69] J. P. Wisnivesky, M. Bonomi, C. Henschke, M. Iannuzzi, and T. McGinn, "Radiation therapy for the treatment of unresected stage I-II non-small cell lung cancer," Chest, vol. 128, no. 3, pp. 1461-1467, 2005.

[70] F. J. Lagerwaard, N. E. Verstegen, C. J. A. Haasbeek et al., "Outcomes of stereotactic ablative radiotherapy in patients with potentially operable stage i non-small cell lung cancer," International Journal of Radiation Oncology, Biology, Physics, vol. 83, no. 1, pp. 348-353, 2012.

[71] O. S. H. Chan, R. M. W. Yeung, A. W. M. Hung et al., "Stereotactic ablative radiotherapy for medically inoperable early stage lung cancer: early outcomes," Hong Kong Medical Journal, vol. 18, no. 5, pp. 412-418, 2012.

[72] C. J. A. Haasbeek, F. J. Lagerwaard, B. J. Slotman, and S. Senan, "Outcomes of stereotactic ablative radiotherapy for centrally located early-stage lung cancer," Journal of Thoracic Oncology, vol. 6, no. 12, pp. 2036-2043, 2011.

[73] A. J. Fakiris, R. C. McGarry, C. T. Yiannoutsos et al., "Stereotactic body radiation therapy for early-stage non-small-cell lung carcinoma: four-year results of a prospective phase II study," International Journal of Radiation Oncology, Biology, Physics, vol. 75, no. 3, pp. 677-682, 2009.

[74] H. Bilal, S. Mahmood, B. Rajashanker, and R. Shah, "Is radiofrequency ablation more effective than stereotactic ablative radiotherapy in patients with early stage medically inoperable nonsmall cell lung cancer?" Interactive Cardiovascular and Thoracic Surgery, vol. 15, no. 2, pp. 258-265, 2012.

[75] R. Timmerman, R. Paulus, J. Galvin et al., "Stereotactic body radiation therapy for inoperable early stage lung cancer," The Journal of the American Medical Association, vol. 303, no. 11, pp. 1070-1076, 2010.

[76] C. Sun, D. Ansari, R. Andersson, and D.-Q. Wu, "Does gemcitabine-based combination therapy improve the prognosis of unresectable pancreatic cancer?" World Journal of Gastroenterology, vol. 18, no. 35, pp. 4944-4958, 2012.

[77] D. R. Xie, H. L. Liang, Y. Wang, S. S. Guo, and Q. Yang, "Meta-analysis on inoperable pancreatic cancer: a comparison between gemcitabine-based combination therapy and gemcitabine alone," World Journal of Gastroenterology, vol. 12, no. 43, pp. 6973-6981, 2006.

[78] J.-K. Kang, M.-S. Kim, C. K. Cho et al., "Stereotactic body radiation therapy for inoperable hepatocellular carcinoma as a local salvage treatment after incomplete transarterial chemoembolization," Cancer, vol. 118, no. 21, pp. 5424-5431, 2012.

[79] J. K. O'Connor, J. Trotter, G. L. Davis, J. Dempster, G. B. Klintmalm, and R. M. Goldstein, "Long-term outcomes of stereotactic body radiation therapy in the treatment of hepatocellular cancer as a bridge to transplantation," Liver Transplantation, vol. 18, no. 8, pp. 949-954, 2012.

[80] D. L. Andolino, C. S. Johnson, M. Maluccio et al., "Stereotactic body radiotherapy for primary hepatocellular carcinoma," International Journal of Radiation Oncology Biology Physics, vol. 81, no. 4, pp. e447-e453, 2011. 
[81] R. A. Ibarra, D. Rojas, L. Snyder et al., "Multicenter results of stereotactic body radiotherapy (SBRT) for non-resectable primary liver tumors," Acta Oncologica, vol. 51, no. 5, pp. 575-583, 2012.

[82] C. Sandroussi, L. A. Dawson, M. Lee et al., "Radiotherapy as a bridge to liver transplantation for hepatocellular carcinoma," Transplant International, vol. 23, no. 3, pp. 299-306, 2010.

[83] D. T. Chang, D. Schellenberg, J. Shen et al., "Stereotactic radiotherapy for unresectable adenocarcinoma of the pancreas," Cancer, vol. 115, no. 3, pp. 665-672, 2009.

[84] J. C. M. Rwigema, D. E. Heron, S. D. Parikh et al., "Adjuvant stereotactic body radiotherapy for resected pancreatic adenocarcinoma with close or positive margins," Journal of Gastrointestinal Cancer, vol. 43, no. 1, pp. 70-76, 2012.

[85] D. Schellenberg, J. Kim, C. Christman-Skieller et al., "Singlefraction stereotactic body radiation therapy and sequential gemcitabine for the treatment of locally advanced pancreatic cancer," International Journal of Radiation Oncology, Biology, Physics, vol. 81, no. 1, pp. 181-188, 2011.

[86] B. M. Barney, K. R. Olivier, R. C. Miller, and M. G. Haddock, "Clinical outcomes and toxicity using Stereotactic Body Radiotherapy (SBRT) for advanced cholangiocarcinoma," Radiation Oncology, vol. 7, no. 1, article no. 67, 2012.

[87] F. A. Polistina, R. Guglielmi, C. Baiocchi et al., "Chemoradiation treatment with gemcitabine plus stereotactic body radiotherapy for unresectable, non-metastatic, locally advanced hilar cholangiocarcinoma. Results of a five year experience," Radiotherapy and Oncology, vol. 99, no. 2, pp. 120-123, 2011.

[88] G. De Meerleer, V. Khoo, B. Escudier et al., "Radiotherapy for renal-cell carcinoma," The Lancet Oncology, vol. 15, no. 4, pp. e170-e177, 2014.

[89] P. J. Wersäll, H. Blomgren, I. Lax et al., "Extracranial stereotactic radiotherapy for primary and metastatic renal cell carcinoma," Radiotherapy and Oncology, vol. 77, no. 1, pp. 88-95, 2005.

[90] J. J. Beitler, D. Makara, P. Silverman, and G. Lederman, "Definitive, high-dose-per-fraction, conformal, stereotactic external radiation for renal cell carcinoma," American Journal of Clinical Oncology, vol. 27, no. 6, pp. 646-648, 2004.

[91] C. Svedman, K. Karlsson, E. Rutkowska et al., "Stereotactic body radiotherapy of primary and metastatic renal lesions for patients with only one functioning kidney," Acta Oncologica, vol. 47, no. 8, pp. 1578-1583, 2008.

[92] S. Siva, D. Pham, S. Gill, N. M. Corcoran, and F. Foroudi, "A systematic review of stereotactic radiotherapy ablation for primary renal cell carcinoma," BJU International, vol. 110, no. 11 B, pp. E737-E743, 2012.

[93] P. M. L. Teo, W. H. Kwan, A. T. C. Chan, W. Y. Lee, W. W. K. King, and C. O. Mok, "How successful is high-dose ( $\leq 60 \mathrm{~Gy})$ reirradiation using mainly external beams in salvaging local failures of nasopharyngeal carcinoma?" International Journal of Radiation Oncology Biology Physics, vol. 40, no. 4, pp. 897-913, 1998.

[94] C. Suárez, J. P. Rodrigo, A. Rinaldo, J. A. Langendijk, A. R. Shaha, and A. Ferlito, "Current treatment options for recurrent nasopharyngeal cancer," European Archives of Oto-RhinoLaryngology, vol. 267, no. 12, pp. 1811-1824, 2010.

[95] G. Ozyigit, M. Cengiz, G. Yazici et al., "A retrospective comparison of robotic stereotactic body radiotherapy and three-dimensional conformal radiotherapy for the reirradiation of locally recurrent nasopharyngeal carcinoma," International Journal of Radiation Oncology, Biology, Physics, vol. 81, no. 4, pp. e263-e268, 2011.

[96] H. Iwata, K. Tatewaki, M. Inoue, N. Yokota, K. Sato, and Y. Shibamoto, "Salvage stereotactic reirradiation using the CyberKnife for the local recurrence of nasal or paranasal carcinoma," Radiotherapy and Oncology, vol. 104, no. 3, pp. 355-360, 2012.

[97] S. Dewas, J. E. Bibault, X. Mirabel et al., "Robotic image-guided reirradiation of lateral pelvic recurrences: preliminary results," Radiation Oncology, vol. 6, no. 1, p. 77, 2011.

[98] A. Sahgal, C. Ames, D. Chou et al., "Stereotactic body radiotherapy is effective salvage therapy for patients with prior radiation of spinal metastases," International Journal of Radiation Oncology Biology Physics, vol. 74, no. 3, pp. 723-731, 2009.

[99] C. Y. H. Choi, J. R. Adler, I. C. Gibbs et al., "Stereotactic radiosurgery for treatment of spinal metastases recurring in close proximity to previously irradiated spinal cord," International Journal of Radiation Oncology Biology Physics, vol. 78, no. 2, pp. 499-506, 2010.

[100] F. Sterzing, H. Hauswald, M. Uhl et al., "Spinal cord sparing reirradiation with helical tomotherapy," Cancer, vol. 116, no. 16, pp. 3961-3968, 2010.

[101] A. K. Garg, X.-S. Wang, A. S. Shiu et al., "Prospective evaluation of spinal reirradiation by using stereotactic body radiation therapy: the university of Texas MD Anderson cancer center experience," Cancer, vol. 117, no. 15, pp. 3509-3516, 2011.

[102] U.-K. Chang, W.-I. Cho, M.-S. Kim, C. K. Cho, D. H. Lee, and C. H. Rhee, "Local tumor control after retreatment of spinal metastasis using stereotactic body radiotherapy; comparison with initial treatment group," Acta Oncologica, vol. 51, no. 5, pp. 589-595, 2012.

[103] A. Mahadevan, S. Floyd, E. Wong, S. Jeyapalan, M. Groff, and E. Kasper, "Stereotactic body radiotherapy reirradiation for recurrent epidural spinal metastases," International Journal of Radiation Oncology Biology Physics, vol. 81, no. 5, pp. 1500-1505, 2011.

[104] A. W. Blackstock and R. Govindan, "Definitive chemoradiation for the treatment of locally advanced non-small-cell lung cancer," Journal of Clinical Oncology, vol. 25, no. 26, pp. 41464152, 2007.

[105] E. L. Gressen, M. Werner-Wasik, J. Cohn, A. Topham, and W. J. Curran Jr., "Thoracic reirradiation for symptomatic relief after prior radiotherapeutic management for lung cancer," American Journal of Clinical Oncology, vol. 23, no. 2, pp. 160-163, 2000.

[106] I. M. Poltinnikov, K. Fallon, Y. Xiao, J. E. Reiff, W. J. Curran Jr., and M. Werner-Wasik, "Combination of longitudinal and circumferential three-dimensional esophageal dose distribution predicts acute esophagitis in hypofractionated reirradiation of patients with non-small-cell lung cancer treated in stereotactic body frame," International Journal of Radiation Oncology, Biology, Physics, vol. 62, no. 3, pp. 652-658, 2005.

[107] P. Kelly, P. A. Balter, N. Rebueno et al., "Stereotactic body radiation therapy for patients with lung cancer previously treated with thoracic radiation," International Journal of Radiation Oncology Biology Physics, vol. 78, no. 5, pp. 1387-1393, 2010.

[108] D. Coon, A. S. Gokhale, S. A. Burton, D. E. Heron, C. Ozhasoglu, and N. Christie, "Fractionated stereotactic body radiation therapy in the treatment of primary, recurrent, and metastatic lung tumors: the role of positron emission tomography/computed tomography-based treatment planning," Clinical Lung Cancer, vol. 9, no. 4, pp. 217-221, 2008.

[109] http://www.janes.com/article/44214/us-government-could-morethan-double-industry-s-f-35-affordability-investment.

[110] http://www.journal.forces.gc.ca/vol12/no2/18-wilner-eng.asp. 


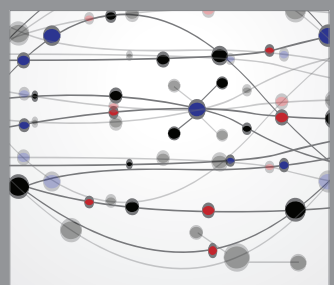

The Scientific World Journal
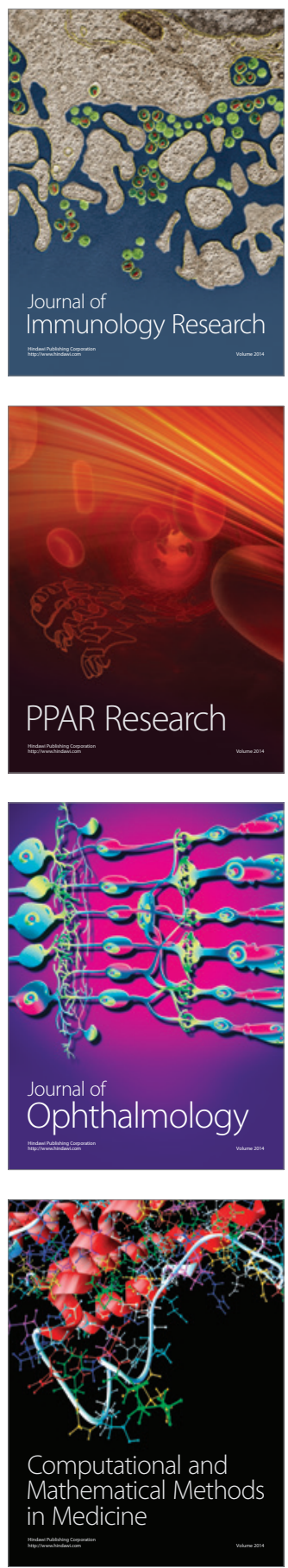

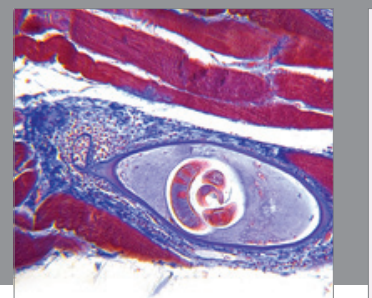

Gastroenterology

Research and Practice
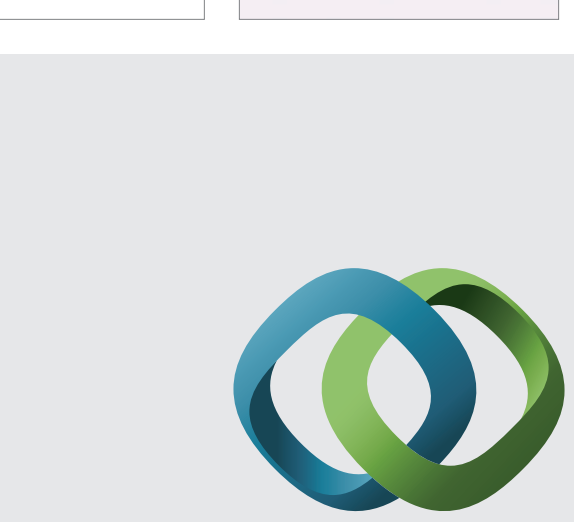

\section{Hindawi}

Submit your manuscripts at

http://www.hindawi.com
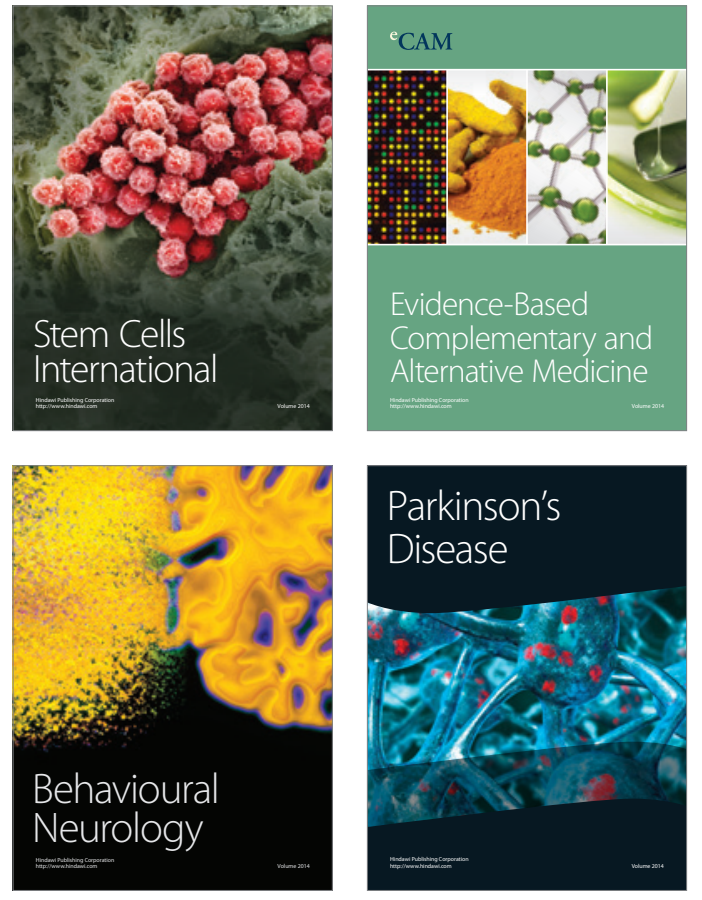
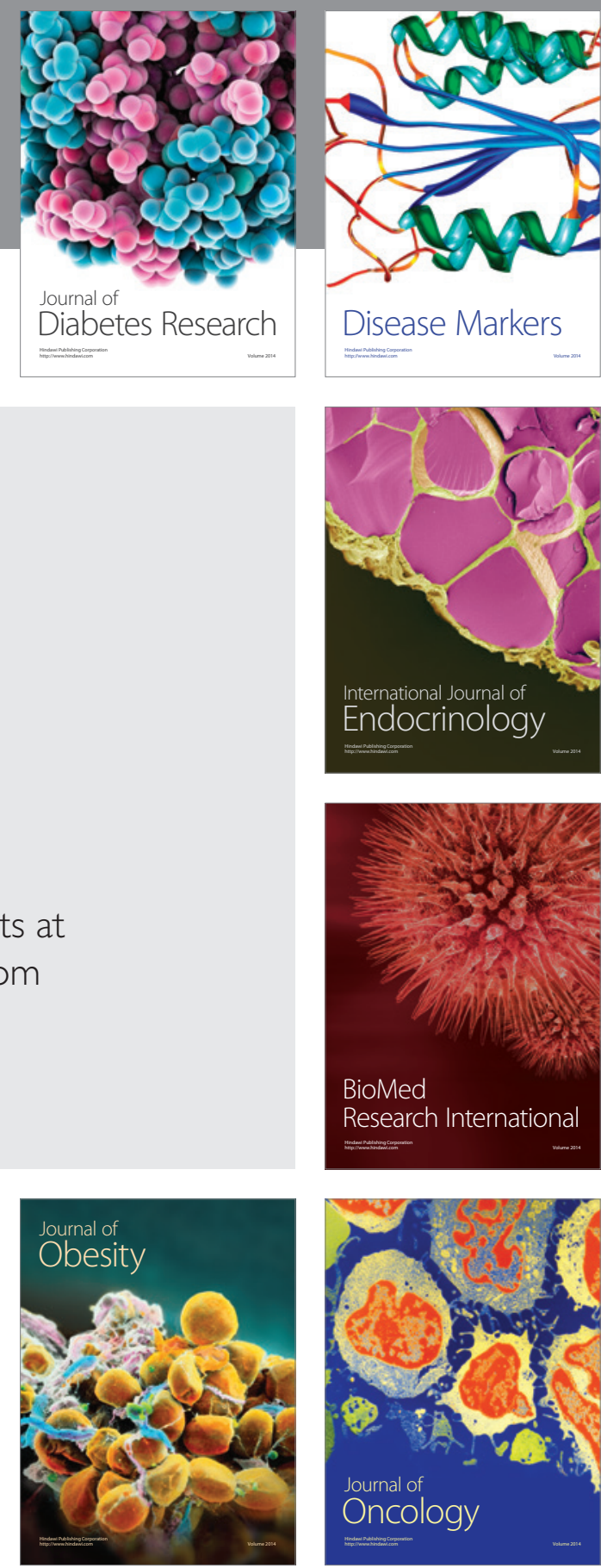

Disease Markers
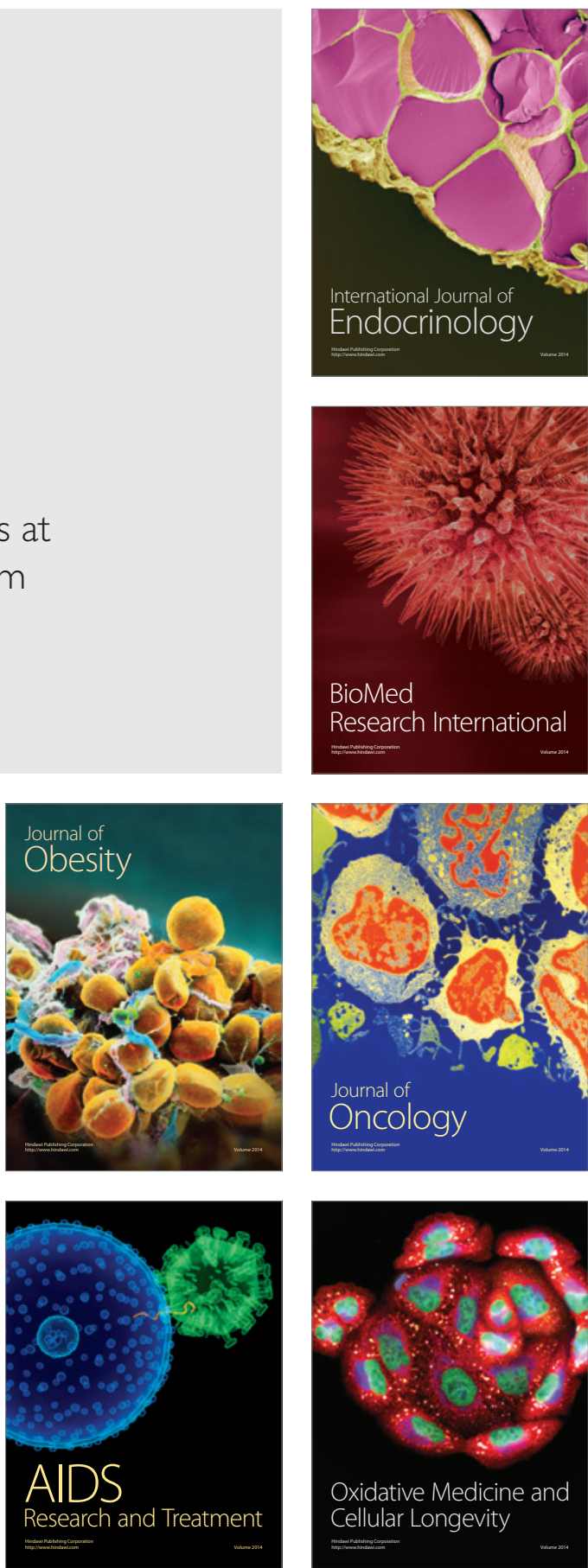